\title{
毛髪のパーマネントウェーブ形成における緩和処理の効果
}

\author{
京都女子大学 櫻井慶子・上甲恭平
}

\section{Effects of Some Relaxation Treatments on the Waving Performance of the Permanent Waving Procedure of Human Hair}

\author{
Keiko Sakurai and Kyohei Joko
}

\author{
Kyoto Women’s University, Kita-hiyoshi, Imakumano, Higashiyama-ku, Kyoto 605-8501, Japan
}

\begin{abstract}
The relaxation behavior on the permanent waving performance of human hair were investigated. According to a standard procedure simulating commercial practice, hair tresses were wrapped on a rod $12 \mathrm{~mm}$ in diameter and were waved by immersing in 5\% thioglycolic acid solution, rinsing with water and neutralization with sodium bromate solution. The relaxation processing was applied after water rinse and carried out remaining the rod under the various conditions for a certain period of time. The effects of the relaxation processing were observed for the hair samples treated for 3-15 minutes with the reduction solution. This wave imparted by added relaxation processing was stronger and shorter than in the absence of relaxation. This indicates that the mechanical relaxation may occur simultaneously and moderately with the protein chains of keratin structure with a much lower conversion of disulfide to sulfhydril group. Accordingly, if the permanent waving of hair is carried out by the produce involving the relaxation processing, the reduction state in the hair necessary for the protein chain rearrangement to equilibrium with the curled configuration can be attained with a smaller concentration of sulfhydril groups, so that the permanent waving produce involving the relaxation processing results in major benefits of fiber degradation as observed by appearance and feel.
\end{abstract}

(Received 10 May, 2010 ; Accepted 21 June, 2010)

\section{1. 緒 言}

毛髪にウェーブをつける施術法には, 様々な方法が試 みられてきたが, 現在ではコールドパーマネントウェー ブ法が主に使用されといる.コールドパーマネントウェー ブ法の基本技術は半世紀前に確立され現在においても基 本は変わらない[1-4].この方法によるパーマネントウェー ブ形成理論については古くから検討され議論され, 現段 階では,「コルテックス細胞を構成する IF/Mx 組織内のシ スチン (-SS-) 結合が還元剤により切断され(還元)，その切 断に伴いIF が新たな位置に再配向 (構造的再配列) し, 酸 化剂により Mxでの-SS-結合を再結合(酸化)させることで ウェーブを形成する」との考えが広く受け入れられてい る[5].

この理論は還元剤との反応による-SS-結合の切断/再結 合をべースとしたものであり，そのため還元処理条件と 毛髪内部の還元領域や-SS-還元量との関係に主眼をおいた 研究が多く報告されている [6-14]. その一方で, Bogaty[15] は，毛髮をロッドに卷き 15 分還元処理した後，水洗した 毛髮をへリウム䨌囲気下で 3 時間を放置し, 酸化剂処理 をせずに乾燥させた毛髪試料をチオグリコール酸溶液と 臭化リチウム溶液で処理する実験を行い，チオグリコー
ル酸溶液処理ではウェーブ形状に変化が認められなかっ たのに対し，臭化リチウム溶液処理ではウェーブがほと んど消えてしまうことを報告した，このことから，彼は ウェーブの形成やその安定性に-SS-結合だけでなく水素結 合やイオン結合などの二次結合が重要な働きをしている と結論した。

また，この報告では特に論じられていないが, 結果を 見る限りヘリウム雲囲気下で放置した毛髪のウェーブ形 状が放置させず酸化処理した毛髪のウェーブ形状に比べ, 毛髪全長が短くよりしっかりとウェーブが出ていた。こ の現象は, 彼の考えに従えばウェーブ形成に還元郕によ り-SS-結合が切断されていない非還元部位での二次結合の 切断/再結合にともなう緩和現象が関係していることを示 すものである. しかしながら, 彼の報告以後非還元部位 での緩和現象に着目した研究や議論はほとんど見あたら ない.ところで, 通常のコールドパーマネントウェーブ 法では還元郕存在下で-SS-結合の切断と構造的再配列が進 行しており, 非還元部位での緩和現象を捉えることがで きない.

そこで, 我々は還元剤による-SS-結合切断反応と還元剂 の作用を受けていない非還元部位の構造的再配列を切り 離して検討することから, ウェーブ形状におよぼす非還 
元部位での構造的再配列の影響を明らかにすることを目 的とした. 本研究では, 還元剤による-SS-結合切断処理後, 十分に水洗することで繊維内部に残存する還元剤の影響 を極力抑えた状態で放置処理(本報告では緩和処理と称 す)する方法を試みた。本報告では, 得られたウェーブ形 状をマクロ的に観察することから, 緩和処理効果および 緩和処理条件について検討を行い, ウェーブ形成に関わ る還元部位と非還元部位での緩和挙動の役割について考 察することとした.

\section{2. 実 験}

\section{1 試料および試薬}

毛髪試料として化学的処理が施されていない 3 人の中 国人女性 $(30 \sim 25$ 歳)の毛髪を使用した。実験に使用する 毛束の精製方法は以下の手順で行った. 毛髪長 $20 \mathrm{~cm}$ 重量 $0.4 \mathrm{~g}$ の毛束を作成し，1\%のドデシルスルフォン酸ナトリ ウム水溶液を $30^{\circ} \mathrm{C}$ の恒温槽にて 10 分間洗浄した. その 後流水で十分に水洗し, 風乾した.

試薬として，チオグリコール酸アンモニウム(チオグリ コール酸含量 $50 \%$ ), 臭素酸ナトリウム, リン酸水素二ナ トリウム, $25 \%$ アンモニア水, $85 \%$ リン酸を用いた。

\section{2 パーマネント処理方法}

基本となるパーマネント処理方法は, 還元処理一水洗一 (緩和処理)-酸化処理の手順で行った.

\subsection{1 還元処理}

還元処理溶液は，チオグリコール酸アンモニウム $10 \mathrm{ml}$ に蒸留水を加え全量を $100 \mathrm{ml}(5 \%$ チオグリコール酸水溶 液)とした後, $25 \%$ アンモニアで pH9.0に調節した.この 溶液を試験管に $12 \mathrm{ml}$ 量り取り, 直径 $12 \mathrm{~mm}$ のロッドに水 巻きした毛束を浸漬した. 試験管は $35^{\circ} \mathrm{C}$ の恒温槽で所定 時間放置した。

\subsection{2 中間水洗}

還元処理後, 試料を流水で 30 秒間水洗し,さらに, $100 \mathrm{ml}$ の蒸留水に 30 秒間浸漬水洗した. その後, 軽く水分をふ き取った。

\subsection{3 緩和処理}

[ラップ法]水洗後の還元毛束をラップで覆い, 一定温度 の乾燥機で所定時間放置した.

[水中浸漬法]水洗後の還元毛束を, 恒温槽で一定温度に 保った蒸留水 $12 \mathrm{ml}$ 入った試験管中に浸漬し, 所定時間放 置した.

[ラップ法/振動法]水洗後の還元毛束をラップで覆い振動 歯ブラシの振動部に装着して, $35^{\circ} \mathrm{C}$ を保った乾燥機中に て規定の振動数で一定時間振動を与えた.

[水中浸漬/超音波法]水洗後の還元毛束を, $35^{\circ} \mathrm{C}$ に保った 超音波水洗器中に蒸留水 $12 \mathrm{ml}$ 入った試験管中に浸漬し, 規定の超音波振動数で一定時間処理した.

\subsection{4 酸化処理}

酸化処理溶液は, 臭素酸ナトリウム $7.5 \mathrm{~g}$ とリン酸水素

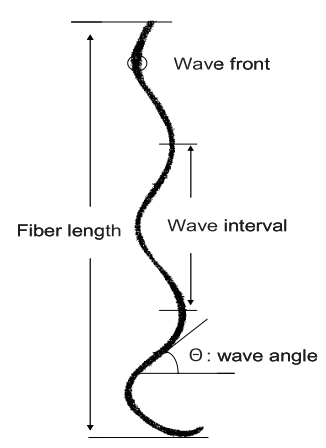

Fig. 1 Parameters of the weaving performance.

二ナトリウム $2 \mathrm{~g}$ を蒸留水 $100 \mathrm{ml}$ に溶解し, リン酸水溶液 で pH6 に調節する。この溶液を $12 \mathrm{ml}$ 試験管に量り取り, 試料毛束を浸漬した後, $35^{\circ} \mathrm{C}$ の恒温槽にて 10 分間処理し た.

\section{2 .5 水洗}

酸化処理後, 試料を蒸留水で十分に水洗し, ロッドか ら外し, 同様に水洗した後, 風乾した.

\section{3 ウェーブ形状の評価}

ウェーブ形状の評価は, ウェーブ形状モデル(図 1)に示 した毛髪長, ウェーブ山数, ウェーブ間隔およびウェー ブ角のパラメーターにより行った。

\section{3. 結 果}

\section{1 [還元/水洗/酸化]処理法による還元処理と ウェーブ形状との関係}

図 2 に還元時間を 3 分〜 50 分まで変化させた毛髪 $\mathrm{A}$, B, Cの湿潤時および乾燥時のウェーブ形状を示した. 図 から明らかなように, 湿潤時および乾燥時のいずれにお いても, 毛髪 $\mathrm{A}, \mathrm{B}, \mathrm{C}$ により若干の差はあるものの, 還 元時間とウェーブ形状との関係はほぼ同じ関係が認めら れる.この関係をウェーブ山数とウェーブ毛髪長とで評 価した。

まず, 湿潤時におけるウェーブ山数であるが, 還元時 間 5 分までは 3 ないし 4 山であるが, 10 分以上では 6〜7 山とウェーブ山数が増加している. また, ウェーブ毛髪 長では, 20 分から 30 分までは還元時間とともに短くなる が, それ以上ではほとんど変わらないか若干長くなる傾 向が認められる.

一方, 乾燥後では, すべての試料でウェーブ山数は乾 燥により変化しないが, ウェーブ毛髪長は明らかに伸び, ウェーブ角の浅い形状となっている. しかし, 還元時間 とウェーブ形状とで湿潤時で見られた関係は乾燥時でも 維持されていた.

以上, 観察された現象は実際のサロンにおけるコール ドパーマ処理においても経験的に知られており, 還元剂 の内部拡散によるジスルフィド結合の還元開裂に関係し ていると考えられてきた[14].

これまでの考えに従えば, 図 2 の結果はジスルフィド 

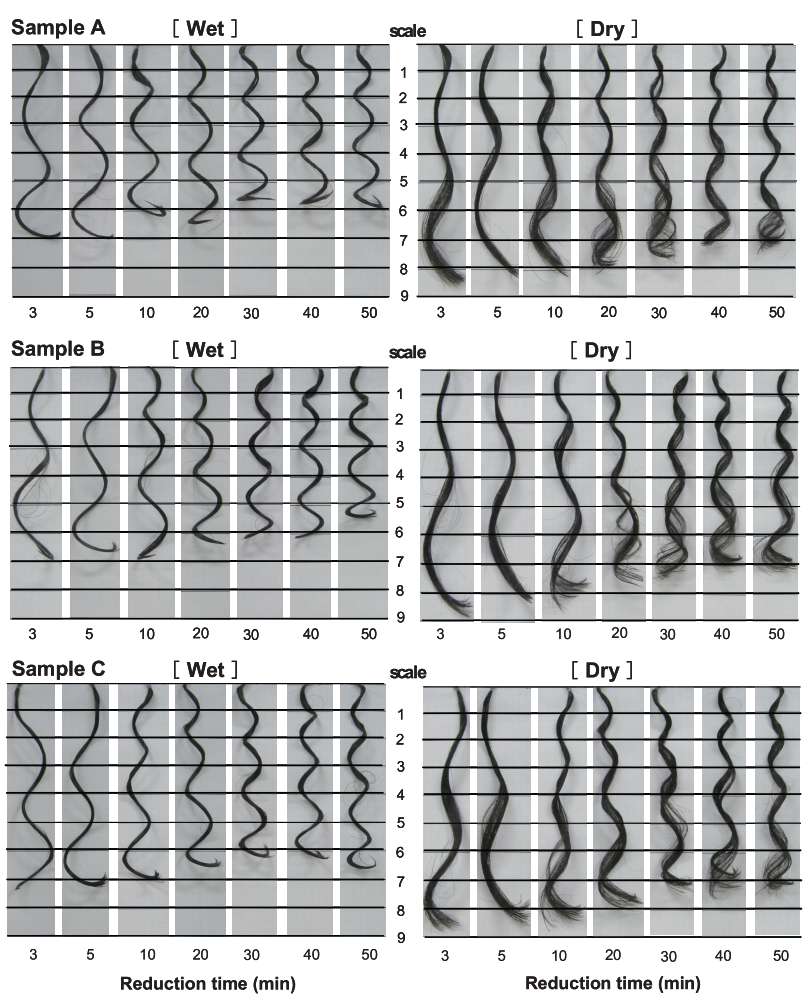

Fig. 2 The relationship between reduction time and the waving performance of the permanent waved hair tresses (Sample A, B and C) treated by simulating a standered waving procedure consisting in treating with ammonium thioglycolate solution, rinsing with water and neutralization with a dilute sodium blomate solution.

[Wet] : waving performance in the wet state,

[Dry] : waving performance in the dry state.

結合の還元度には最適還元度が存在し, 最適還元度では ロッド径に依存したウェーブ山数とウェーブ角を持つ毛 髪長が最短となるウェーブが得られことになる。しかし， Bogaty[15]の結果は, 最適ウェーブ形成には非還元部位 での構造的再配列の寄与を考慮する必要のあることを示 唆している.

\section{$3.2[$ 還元/水洗/緩和/酸化]処理法による緩和処理 の効果}

\subsection{1 ラップ緩和処理 (ラップ法) とウェーブ形状}

基本的な緩和処理は, 一定時間還元処理した後, 繊維 内外に存在する過剩な還元剤を洗い流し, 湿潤状態のま ま一定時間保持することで行う。まずは, 水洗後の湿潤 状態をラップで覆うことで保持させたラップ法での還元 時間と緩和処理時間との関係を調べた。

図 3 は還元時間を $3 ， 5 ， 10 ， 15 ， 30$ ，および 50 分とし， 還元 15 分処理までは合計時間が 30 分となるように $35^{\circ} \mathrm{C}$ で緩和処理した場合の，還元処理 30 分および 50 分では 緩和処理 15 分とした場合の湿潤状態および一日放置後の 乾燥状態でのウェーブ形状を示したものである.

まず, 湿潤状態での還元時間ごとのウェーブ山数は, いずれの毛髪サンプルにおいても図 2 のパーマ処理毛髪
とほほ同数であった. 次に, 毛髪長については, 図 2 で 見られたような還元時間との明確な関係は見られない.

これは，3，5，10 分還元処理毛髪の毛髪長が短くなった ためであり，明らかに緩和処理の効果が認められる.

一方, 乾燥状態でのウェーブ形状では, ウェーブ山数 に変化はないが, 毛髪長は, いずれのサンプルも 1.5 から 2 目盛伸びるが，3，5，10 分還元試料では，図 2 の同一 還元時間試料と比べて短くなっていた．特に，10 分還元 処理サンプルではその効果が顕著であり，15 分以上の還 元サンプルとほぼ同等の毛髪長となっている.また, 30 分以上の還元処理サンプルでは，乾燥することにより図 2 のサンプルとほぼ同じ毛髪長まで伸び，湿潤状態で見ら れた緩和処理効果は見かけ上消滅した。

以上のように，ラップ法による緩和処理は短時間還元
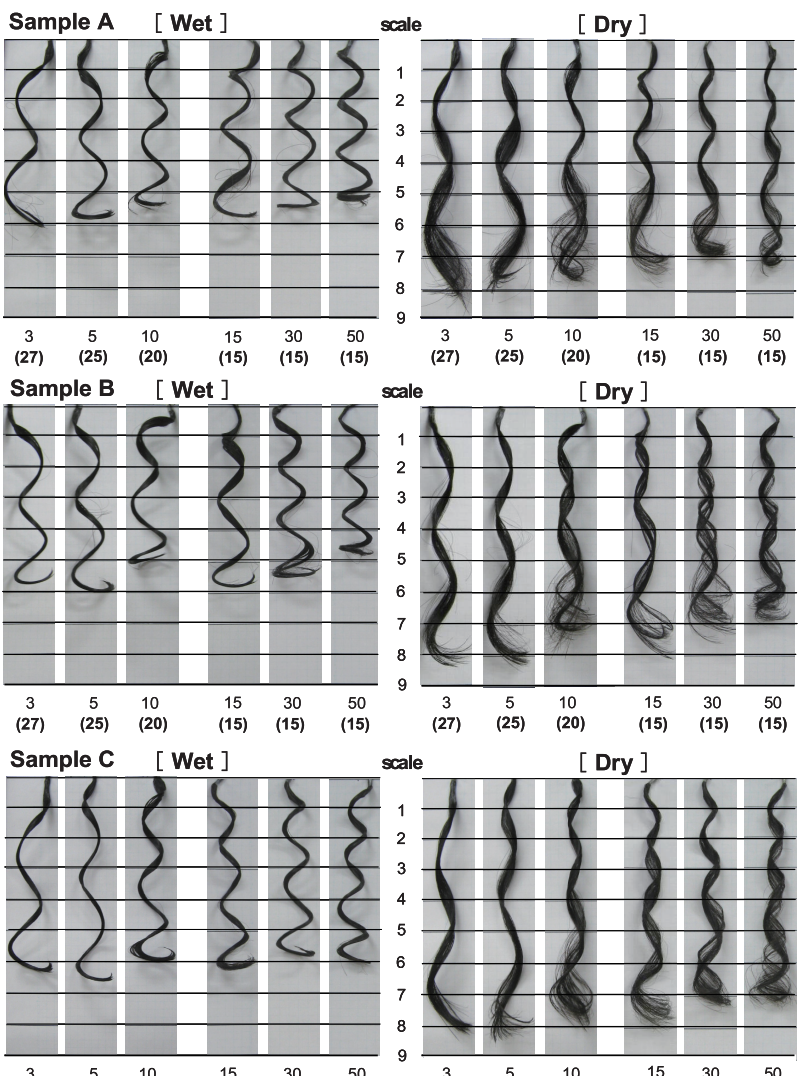

$\begin{array}{cccccc}3 & 5 & 10 & 15 & 30 & 50 \\ \mathbf{( 2 7 )} & \mathbf{( 2 5 )} & \mathbf{( 2 0 )} & \mathbf{( 1 5 )} & \mathbf{( 1 5 )} & \mathbf{( 1 5 )}\end{array}$

Treatment time ( $\mathrm{min})$
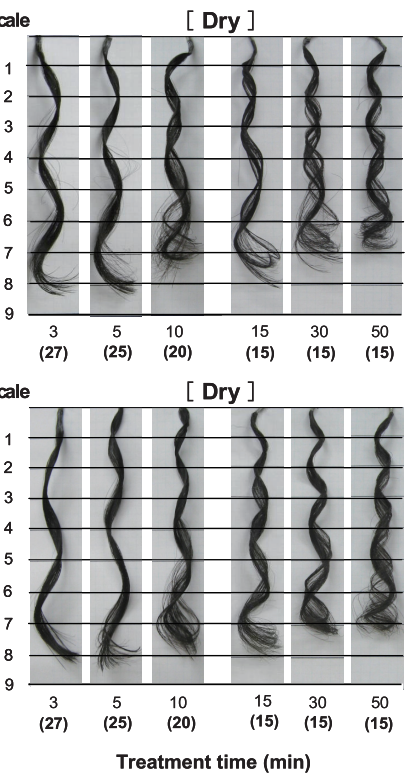

Fig. 3 The effects of relaxation processing with wrapping method on the waving performance of the permanent waved hair tresses. Hair tresses were waved by treating with reduction solution for a fixed time, rinsing with water, remaining on the rods wrapped with plastic film for a certain period of time (relaxation process) and neutralization.

Treatment time implies the reduction time and the relaxation time: the upper numerals represent the reduction time and the lower numerals in parentheses represent the relaxation time. 
処理毛髪の毛髪長の短縮化が促され, シャープなカール を形成するように作用した，また，本実験では 10 分還元 処理毛髪では緩和処理を施すことで通常法による最適還 元度で得られるウェーブ形状と同等の形状が得られた。

以下では, ウェーブ毛髪の毛髪長に着目し, 毛髪長を 最短にするための最適緩和処理条件について検討した.

\subsection{2 ラップ法での緩和処理時間の影響}

緩和処理効果が顕著に現れた 10 分還元毛髪サンプル (毛髪 A)を用いて緩和処理時間の影響について検討した。 図 4 にラップ緩和処理時間と処理毛髪の湿潤状態および 乾燥状態でのウェーブ形状との関係を示した.

まず, 湿潤時でのウェーブ形状であるが, ウェーブ山 数では緩和 10 分処理で 5 山であったが, その後は 6〜7 山となり，毛髪長では 4 時間までは処理時間とともに毛 髪長が短くなるが, それ以上ではほとんど変わらないこ とがわかる. 次に, 乾燥時でのウェーブ形状では, ウェー ブ山数は変わらず, 毛髪長と緩和時間との関係は湿潤時 で見られた緩和処理の効果をほぼ維持している.しかし， 長時間処理において乾燥毛髪長は目盛り 7 より短くなる ことはない.

これらの結果から, 乾燥後のウェーブ毛髪長を最短に する上で緩和処理を長時間施すことの効果はほとんど期 待できないことがわかる.

\subsection{3 ラップ法での緩和処理温度の影響}

続いて, 10 分還元毛髪サンプル (毛髪 A) を用いて緩和 処理時間を 10 分とし, 処理温度 $\left(35^{\circ} \mathrm{C} \sim 85^{\circ} \mathrm{C}\right)$ を変えた場 合のウェーブ形状から処理温度の効果について検討し, その結果を図 5 に示した.

湿潤時および乾燥時のいずれの場合も, ウェーブ山数 に対しては $45^{\circ} \mathrm{C}$ で 1 山増加し, それ以上の温度では毛先 のカールが強くなるものの, 山数そのものはほとんど変 化していない. 一方, 毛髪長は温度上昇とともに短くな り, $65^{\circ} \mathrm{C}$ で最短となる, その後は温度とともに伸びてい る.

これらの結果から, 乾燥後のウェーブ毛髪長を最短に する上で緩和処理温度は高い方が効果は認められるが, 最適温度が存在するようであり, それ以上の温度では逆 効果になることが明らかになった.

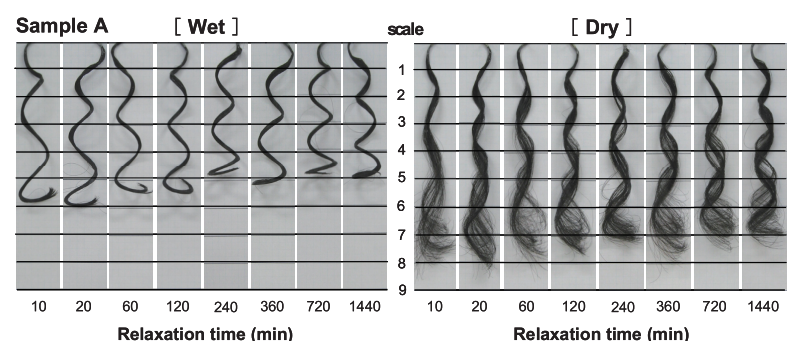

Fig. 4 The relationship between relaxation time and the waving performance of the permanent waved hair tresses treated with the reduction solution for 10 minutes waved by the waving procedure involving relaxation process.

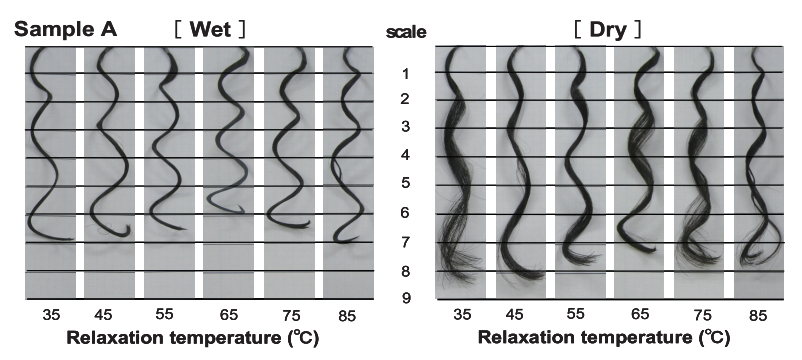

Fig. 5 The relationship between relaxation temperature and the waving performance of the permanent waved hair tresses waved by the waving procedure involving relaxation process.

Reduction carried out with the reduction solution for 10 minutes.

\section{3 水浸漬法による緩和処理の効果}

次に, 緩和処理での水分量の影響について調べた。図 6 は還元時間を $3,5,10,15$ 分と変化させ， $35^{\circ} \mathrm{C}$ に保った 水中で浸漬処理した場合のウェーブ形状(毛髪 A)を示し たものである.

図 3 に示したラップ法でのウェーブ形状と比較したと ころ, 湿潤・乾燥時のいずれにおいても, 緩和処理効果 はラップ法では効果があまり見られなかった還元時間 5 分の試料に認められたが, 10,15 分還元試料では認めら れない. ただ, ラップ緩和法に比べウェーブ間隔の均等 性が向上しているようである. 同様の効果は毛髪 B, C に おいても認められた.

このように, 緩和処理時の水分量は還元時間の短い試 料では因子として作用するが, ある時間以上の還元試料 には還元・水洗時に収着した水分で十分であることがわ かる.

\section{4 ラップ/振動緩和法および水浸漬/超音波緩和法 による緩和処理効果}

最後に, 緩和処理中に振動による運動エネルギーを負 荷した場合の効果を調べた. ラップ/振動緩和法では振動 歯ブラシを, 水浸漬/超音波緩和法では超音波洗浄器を用 いて前者では $35^{\circ} \mathrm{C}$ の乾燥機中で, 後者は $35^{\circ} \mathrm{C} に$ 保った 水中で一定時間振動を負荷しながら処理を行った。その

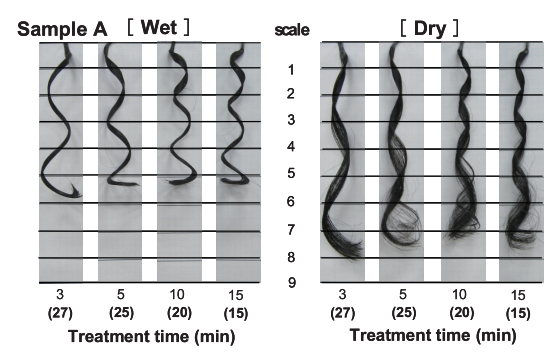

Fig. 6 The effects of relaxation processing with water immersing method on the waving performance of the permanent waved hair tresses. Hair tresses were waved by treating with the waving procedure involving relaxation process which carried out to remain on the rods immersed in distilled water for a certain period of time. 
結果を図 7 に示した

図 $7(\operatorname{method} A)$ の結果を図 3 のラップ法でのウェーブ形 状と比較したところ，まず，毛髪長は湿・乾いずれの場 合も振動を負荷することで長くなっており, さらに，毛 先になるほどウェーブ間隔が広くなることがわかる。一 方, ウェーブ山数は還元時間が短い 3 分処理試料で 1 山 増加し, 15 分試料では 1 山減少した.

一方, 図 $7(\operatorname{method} \mathrm{B})$ に示した水浸漬/超音波緩和法で の処理試料の形状変化は, 図 $7(\operatorname{method} A)$ に示された試料 とほぼ同様の変化であると言えるが，ただ，超音波振動 の場合, 振動エネルギーは処理試料の還元時間により見 かけの効果が異なるように作用していることがわかる.

すなわち, 還元時間 3 分の試料形状は, 図 3 の還元 10 分/緩和 20 分処理試料と同等の形状と見なせることから, 還元時間が短く還元度が低い場合には，超音波振動の運 動エネルギーにより毛髪全体の緩和が進み十分なウェー ブ形状が得られるのに対して，還元時間が長い試料では， 逆に乾燥状態でのウェーブ毛髪長が伸びている.

以上のように，振動によるエネルギー負荷効果は試料 水分量に依存し，水分量の低い場合には振動無負荷の試 料よりも毛髪長が伸びるように現れ, 水分量が多い場合 には, 還元時間の短い毛髪に対してはウェーブ山数が増 加し, 乾燥時での毛髪長も短くなる効果が認められた.

\section{4. 考察}

\section{1 還元処理時間と最適還元度}

改めて図 2 に示した乾燥時での各ウェーブ毛髮の ウェーブ回転数 (1/2 山数) および毛髮長と還元処理時間と の関係を見ると, ウェーブ回転数は還元処理時間にした

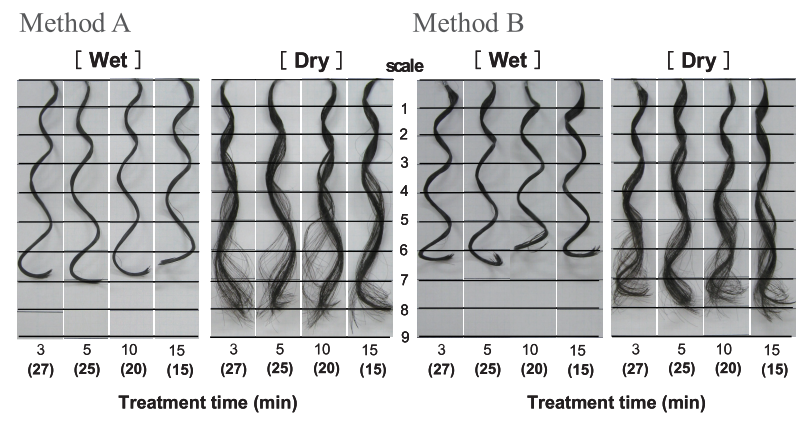

Fig. 7 The effects of relaxation processing with method A (wrapping/vibration method) and method B (water immersing/ultrasonic vibration method) on the waving performance of the permanent waved hair tresses. Hair tresses were waved by treating with reduction solution for a fixed time, water rinsed, allowed to remain on the rods wrapped with plastic film and vibrated by a tooth agitator or on the rods immersed in distilled water and vibrated by ultrasonic cleaning apparatus for a certain period of time and was then neutralized.
がって増加し, 50 分処理で 3 から 3.5 回転となるが, ウェーブ毛髪長は還元時間 20 分〜30 分で最短となり, そ の後はほぼ一定となっていた。

ところで, 美容業界で好ましいとされるウェーブ形状 は，ロッド径に対して 2〜2.5 倍のカール径となるウェー ブであるとされている [16].この基準を今回用いたロッ ド径に当てはめると, 山数は 5 山から 6 山となる. その ための還元処理時間は最短で 10 分必要となる. 一方, よ り弾力性のウェーブとなると全毛髪長ができるだけ短く なる必要があり, 兩者を併せ持つには, 20 分の還元処理 が必要となることがわかる.

この還元時間は Wortmann ら [17]が行ったパーマネント ウェーブ処理毛の曲げ緩和実験において, 還元処理毛髪 の残存曲げ剛性が数\%まで低下する処理時間と一致する. 彼らは, $12 \mathrm{~mm}$ のシリンダーに過剩量の $0.6 \mathrm{M} / \mathrm{L}$ チオグリ コール酸アンモニウム溶液中 $(\mathrm{pH} 9.0)$ に室温下で浸漬した 毛髪の曲げ剛性率(処理毛髪の曲げ剛性/未処理の曲げ剛 性)を測定し， 20 分後の残存曲げ剛性が $5 \%$ まで減少して いることを報告した.

本実験に用いた条件が Wortmann らの実験条件とほぼ同 じであることから, 通常法では還元 20, 30 分処理で処理 毛髪の残存曲げ剛性がほぼ消失していると考えられ, こ の状態がより好ましいウェーブ形状を形成する最適還元 度であることになる。

\section{2 還元部位と非還元部位の存在}

ところで, 本実験での還元処理は浸漬法で行っており 還元剤は毛髪に対して大過剩に存在する。この場合は, 毛髮表面層での還元反応は瞬時に平衡に達し, 処理時間 中一定の反応量を示す.これまでの研究では, チオグリ コール酸による還元反応は拡散が律速であるとされてい る[6]. また，この拡散は Fick則に従い，反応は繊維表面 より纎維内部にかけて漸次低下すると報告されている [18].

さらに，還元条件と-SS-結合の還元量についても報告さ れている. Salceら[13]は, ロッド巻き毛髪を過剩量のチ オグリコール酸アンモニウム溶液 $(0.8 \mathrm{~mol} / \mathrm{L}, \mathrm{pH} 9.3)$ で処 理した後, 生成-SH 基をヨード酢酸で封鎖し, 残存-SS-量 の測定からその還元度を測定した. その結果, 還元時間 20 分でほぼ41.7\%の-SS-結合が切断されていることを報告 した。また，ストレート状態で本実験とほぼ同様の処理 条件で還元した場合の-SS-結合の切断量は還元処理時間が 30 分でほぼ一定となり，90\%に達するとした報告もある [8].

これらの報告からも，30 分以上の還元処理毛髪ではほ ぼチオグリコール酸イオンによる還元反応が進み, 毛髪 全体が高度に還元されていると考えられるのに対して, 緩和処理効果が認められた短時間 (3 分〜15 分) 還元処理 毛髪は還元剂の作用を受けた還元部位と還元剤の作用が 及んでいない非還元部位が存在していることが支持され る[6.17]. 
したがって，[還元/水洗/緩和 (ラップ)/酸化]処理法によ る緩和処理の効果が，還元時間 30 分を境に乾燥による毛 髪長の伸び現象が異なっていたこと，すなわち，還元時 間 15 分以内では毛髪長の短縮化が見られたのに対し, 還 元時間 30 分以上で乾燥時での毛髮長が未緩和処理毛髪試 料の毛髪長まで伸びたことは，還元剤が作用する還元部 位量およびその反応量が関係していることを示している.

\section{3 乾燥によるウェーブ毛髮の伸び現象}

ウェーブ毛髪長の伸びは, 乾燥 (脱膨潤)による毛髪構 成組織の収縮が原因となる伸びと重力方向の応力 (クリー プ現象)による構成分子の構造的再配列が原因となる伸び が考えられる.

図 8 は，[還元(浸漬)/水洗/酸化]処理した毛髪を，ロッ ドから外し平滑な板上で乾燥したサンプル(図 8-I)を ボードに吊した時のウェーブ形状(図 8-II) とその後 1 日 放置した時のウェーブ形状(図 8-III)を示したものである まず, 板の上で乾燥させた場合, 乾燥によってカール直 径は湿潤時のカール直径の 1.2 倍となる. その状態でボー ドに吊すと図 8-II のように, 毛髪長が短い立体感のある ウェーブを示す.このウェーブ毛髪長は, 重力がかから ない場合のウェーブとみなせ, 乾燥のみによるウェーブ の伸びはわずかであるといえる.しかし，1日放置した ウェーブ毛髪は明らかに伸びており,この伸びは重力に よるクリープ現象による伸びであることがわかる.

したがって，[還元/水洗/緩和 (ラップ)/酸化]処理法によ る緩和処理の効果が，還元時間 30 分を境に乾燥による毛 髪長の伸び現象が異なっていたことは，還元部位および 非還元部位の高次構造が重力に対する構造的再配列のし 易さが異なり, 非還元部位の高次構造は, 重力に対して 構造的再々配列が起こりにくい構造であると考えること ができる.

\section{4 非還元部位の構造再配列機構}

\subsection{1 非還元部位の構造的再配列}

パーマネントウェーブの形成は，ロッド巻きおよび膨 潤圧に伴う内部応力の緩和による構造的再配列の結果で ある，既に述べたように，還元時間とともに処理毛髪の

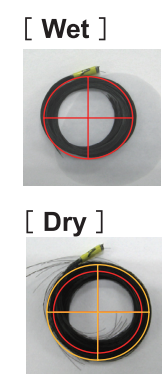

( I)

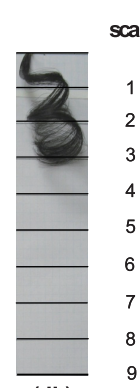

( II)

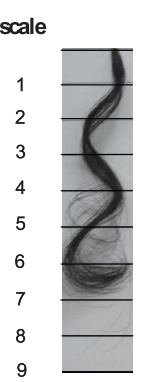

( III)
Fig. 8 (I) changes in curvature diameter of permanent waved hair tress dried on the smooth board and (II) the waved hair tress putted up after drying and (III) the waved hair tress remained on the putting up state for one day.
曲げ剛性は低下し緩和が進むが，この緩和は還元剤と反 応した-SS-結合の切断の寄与によるものと考えられている [6,17]. したがって, 還元部位では-SS-結合の切断により 容易に構造的再配列が起こる $[6,19]$ が, 非還元部位では容 易に緩和が起こらないと考えることができる.

すなわち, 図 3 の緩和処理が施されたウェーブ形状は, この 2 つの部位の割合により発現されたものであり, 緩 和処理時間中に還元部位および非還元部位の残存応力の 緩和が進んだことによる形状であるといえる。ここで述 べた緩和による構造的再配列は, 繊維軸方向での分子再 配列が優先的に起こっているものと考えられる．なぜな らば, 高温での緩和処理あるいは振動エネルギーを負荷 した緩和処理では, 繊維軸方向以外での分子再配列によ る応力緩和が起こり, ウェーブ形成にとって逆効果となっ たことから明らかである.

\subsection{2 二次結合の切断/再結合}

では, 非還元部位での構造的再配列の要因であるが, Bogaty[15]は水素結合やイオン結合などの二次結合の切 断/再結合により生じる再配列であると考えている.すな わち, この再配列機構はウォーターセッティング [20]で の再配列機構と同じである.

そこで，このことを確かめるため還元剤無添加での [還 元/水洗/緩和 (ラップ)/酸化]処理法により毛髪の処理を試 みた。 その結果を図 9 に示す.

この図では, いずれの処理試料もほぼ同じウェーブ形 状であり,その形状は図 2 に示した還元 3 分処理毛髪の それと変わらなかった. このように, 還元反応を伴わな い場合は時間に関係なくほとんどウェーブが形成されて いないことから, 非還元部位での構造再配列は単なる二 次結合の切断/再結合による再配列ではないと言える.

\subsection{3 水洗後の残存還元剂の影響}

中間水洗では，還元剤を極力除去するように試みたが. 繊維内部には除去しきれずに残存する。したがって，一 つの要因として, 残存還元剂による非還元部位の-SS-結合 の還元反応が挙げられる，そこで，まず中間水洗せずに 還元剤溶液が毛髪内部溶液として存在する系でのウェー ブ形成について調べた。

図 10 に[還元/緩和 (ラップ)/酸化]処理法により処理し
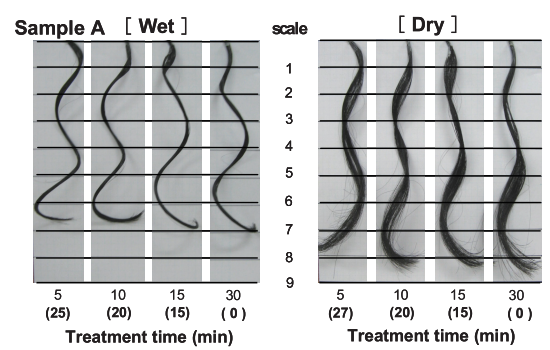

Fig. 9 The waving performance of the waved hair tresses treated with the reduction solution excluding ammonium thioglycolate by the waving procedure involving the wrapping relaxation process. 


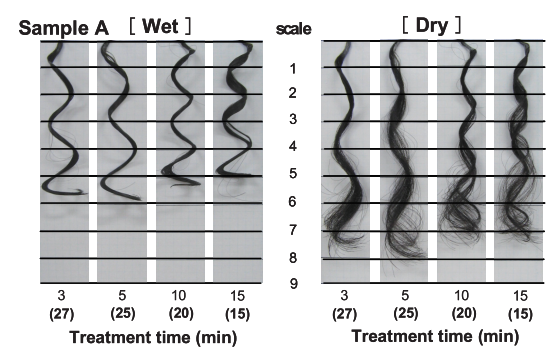

Fig. 10 The waving performance of the permanent waved hair tresses treated by the waving procedure involving the wrapping relaxation process without the intermediate water rinsing process.

た毛髪の乾燥時のウェーブ形状を示した，結果は，浸漬 還元処理 3 分の毛髪試料においてもウェーブが得られて おり，還元剤を洗い流さない効果が認められる.

しかしながら，各毛髪のウェーブ形状を中間水洗によ り還元剤を除去した図 3 のそれらと比較したところ, 浸 漬 3 分処理試料では, 確かに残存還元剂濃度が高い方が ウェーブは得られているが，5 分以上の浸漬処理試料では， 中間水洗により還元剤がほとんど除去された試料の ウェーブ形状とほとんど変わっていない，すなわち，還 元剂の存在量にかかわらず得られるウェーブは変わらな いことを示している，このことは，中間水洗した試料毛 髪中の非還元部位の緩和は，還元剤がもたらす作用と同 様あるいは類似の作用に基づく緩和であることが示唆さ れる.

\subsubsection{SS/SH 交換反応}

では，還元剤がもたらす作用あるいは類似の作用であ るが，まずは還元剤が直接関与する反応で式(1)に表され る-SS-結合の切断作用が考えられる。

$\mathrm{K}-\mathrm{SS}-\mathrm{K}+2 \mathrm{RSH} \rightleftarrows \mathrm{RSSR}+2 \mathrm{KSH}$

(ただし，K-SS-K はジスルフィド結合を，RSH は還元剤 を，KSH はシステインを表している.）しかし，中間水洗 により還元剤を大部分除去した毛髪試料では，残存還元 凨濃度は低く, 非還元部位の-SS-結合が(1)式にしたがっ た反応のみで切断され残存歪みが緩和されるとは考え難い，

一方，類似の作用であるが，(1)式のように還元剤が直 接関与するのでなく, 内部歪みが緩和される機構として 考えられている SS/SH 交換反応が挙げられる。この交換 反応は内部歪みが存在する場合, ケラチン繊維中に生成 したイオン化スルフィドリル $\left(\mathrm{K}-\mathrm{S}^{-}\right)$基が-SS-結合の切断/ 再結合を電子伝達に基づき連鎖的に引き起こす反応であ る.この SS/SH 交換反応による-SS-結合の切断機構は, 羊毛繊維の煮䋐セットや化学セット工程でのセット過程 で働き，七ット工程に扔ける構造的再配列に大きな比率 を占めていることが多くの研究者[21-23]によって確かめ られている.

この羊毛繊維の煮䋐セットや化学セット関係の研究よ り得られた知見を基に, Feughelman[24]は, 毛髪のパー マネントウェーブを与える構造的再配列の主因子は, ジ
スルフィド結合の切断ではなく電子伝達に基づく $\mathrm{SS} / \mathrm{SH}$ 交換反応であり，K-S-基量に依存すると述べている．ま た, 羊毛纎維の化学セットの主因子が, セット浴の $\mathrm{pH}$ と 温度拉よび加工対象布のストレス(歪み)であると考えら れてきたが，そのまま毛髪のパーマネントウェーブの因 子として当てはまるとした，さらに，この考えを実証す るため, $100^{\circ} \mathrm{C}, \mathrm{pH} 9.4$ の 4\%チオグリコール酸アンモニ ウムにロッドに巻いた毛束を 20 秒浸漬, 水洗処理すると したパーマネント処理を試み, この処理で十分なウェー ブが形成されることを報告した。この結果は, 満足する ウェーブを得るための $\mathrm{K}-\mathrm{S}$ 基の生成と $\mathrm{SS} / \mathrm{SH}$ 交換反応に よる応力緩和が, $100^{\circ} \mathrm{C}$ という高温で瞬時に起きたことに よるものである.

以上のことから, 中間水洗後の緩和処理による構造的 再配列は，主に非還元部位の電子伝達に基づく $\mathrm{SS} / \mathrm{SH}$ 交 換反応による-SS-結合の切断/再結合が関与したものであ ると結論できる。

\section{5. 結 論}

本研究では，還元剂による-SS-結合切断反応と還元剤の 作用を受けていない非還元部位の構造的再配列を切り離 して処理することで，ウェーブ形状におよぼす非還元部 位での構造的再配列の影響を検討した，その結果，中間 水洗後のラップ法による緩和処理は, 毛束を構成してい る毛髪一本一本の歪み緩和が進み毛髪形状を均質化する ことから, 毛先のカールおよび毛束のまとまりを向上さ せるように作用することが明らかとなった。また，緩和 処理を施した毛髪ウェーブ形状は，還元時間に応じた ウェーブ山数と毛髪長(ウェーブ角)に現れるが，ある一 定の還元時間を境に乾燥状態での毛髪長に対する緩和処 理効果に差が現れた，ある還元時間より短い還元試料で は, 湿潤時での処理効果が維持され毛髪長が短いウェー ブ形状となるが，還元時間の長い試料では，湿潤時での 処理効果が維持されず，毛髪長は無緩和処理試料の毛髮 長とほぼ同じ長さのウェーブ形状となり, 湿潤時に見ら れた緩和处理効果が消失することがわかった.

このような中間水洗後の緩和処理は, 主に還元剤の作 用を受けていない非還元部位の高次構造の再配列に関与 し，その構造的再配列は応力緩和にために連鎖反応的に 生じる SS/SH 交換反応による-SS-結合の切断/再結合にと もなう再配列であると考えられた，さらにここの機構で 再構成された高次構造は重力方向の応力に対して再配列 が起こりにくい構造であることも示唆された.

以上のことから, 毛髪のコールドパーマネントウェー ブ処理に中間水洗後の緩和処理を組み込むことにより， 還元剂による過㮃な反応による毛髪の損傷を抑えられる だけでなく，非還元部位での構造的再配列がウェーブ性 状に影響を抢よぼすことから，まとまりのある持続性に 富むウェーブが形成されるものと言える. 


\section{文 献}

1. J. W.Haefele, U.S.Pat, 2, 719, 813 (1955).

2. J.W.Haefele, U.S.Pat, 2, 719, 814 (1955).

3. J.H.Sanders, U.S.Pat, 2, 719, 815 (1955).

4. C. Robbins, "Chemical and Physical of Human hair", 4th Ed. Springer-Verlag, New York, Berlin,Hedelbelberg, pp. 142-143 (2002).

5. C. Robbins, "Chemical and Physical of Human hair", 4th Ed. Springer-Verlag, New York, Berlin, Hedelbelberg, pp. 105-106 (2002).

6. F. J. Wortmann, and N. Kure, J. Soc. Cosmet. Chem., 41, 123-139 (1990).

7. M. Feughelman, J. Soc. Cosmet. Chem., 42, 129-131 (1991).

8. C. Yamauchi, A. MochizuKi, K. Takayama, S. Zuzuki, and A. Sakaino, J. Soc. Cosmet. Chem., 60, 527-535 (2009).

9. T. A. Evans, T. M. Venture, amd A. M. Wayne, J. Soc. Cosmet. Chem., 45, 279-298 (1994).

10. R. R. Wicket, and B. G. Barman, J. Soc. Cosmet. Chem., 36, 75-86 (1985).

11. S. Ogawa, K. Fujii, K. Kanayama, and K. Arai, Sen'i Gakkaishi, 64, 137-144 (2008).

12. M. A. Manuszak, E. T. Borish, and R. R. Wicket, J. Soc. Cosmet. Chem, 47, 213-227 (1996).
13. L. Scale, J. J. Cinocotta, S. Barrow, A.Rubinstein, and E. J. Kemm, J. Soc. Cosmet. Chem., 38, 99-107 (1987).

14. G. G. Gumprecht, K. Patel, and R. P. Bono, J. Soc. Cosmet. Chem., 28, 717-732 (1977).

15. H. Bogaty, J. Soc. Cosmet. Chem., 11, 333-342 (1960).

16. Japan Permanent Waving Lotion Industry Association, "SCIENCE of WAVE" Ed. Shinbiyou-Syuppan Co. Ltd, Tokyo, pp. 35 (2006).

17. F. J. Wortmann and N. Kure, J. Soc. Cosmet. Chem., 45, 149-158 (1994).

18. A. Kuzuhara, and T. Hori, polymer, 44. $7963-7970$ (2003).

19. M. Feugehelman, J. Soc. Cosmet. Chem., 42, 129-131 (1991).

20. C.Robbins, "Chemical and Physical of Human hair", 4th Ed. Springer-Verlag, New York, pp. 133-134 (2002).

21. R.Nakamura, and Y.Nemoto, Sen'i Gakkaishi, 17, 428-435 (1961).

22. M.Feughelman, 3th Int. Wool Text, Res, Conf., Paris, Section 2, p255 (1965).

23. C.Robbins, "Chemical and Physical of Human hair", 4th Ed. Springer-Verlag, New York, pp. 135 (2002).

24. M. Feughelman, J. Soc. Cosmet. Chem., 41, 2009-212 (1990). 